\title{
A Place in the Dust: Text, Topography and a Toponymic Note on Micah 1:10-12a*
}

\author{
Matthew J. Suriano \\ Indiana University, Bloomington
}

\begin{abstract}
The poetry of Micah's oracle of doom (Mic 1:8-16) combines two undeniable motifs, the motif of the lament and that of geography. The latter motif is not well understood due to the obscurity of the place names found in $v v \cdot 10 \mathrm{a}-12 \mathrm{~b}$. A careful study of the oracle's geographical context, however, will lead to a more precise understanding of the topography of $v v \cdot 10-12 \mathrm{~b}$ and serve as the basis for the identification of one of the more enigmatic place names, Bethle-aphrah $(v .10 \mathrm{~b})$, with the archaeological site of Tell el-Areini.
\end{abstract}

\section{Keywords}

Micah 1:8-16, history of Judah, Beth-le-aphrah, Hebrew toponyms, Sennacherib’s campaign

\section{Introduction}

The little known place name Beth-le-aphrah of Mic 1:10b appears in a passage filled with equally obscure localities that are framed in a lament over the destruction of Judah's rural countryside (1:8-16). The particular place name occurs in a stanza $(v v, 10-12)$ that begins with Gath but includes hitherto unidentified towns that stand in contrast to the better known (and identifiable) places mentioned in the associated stanza ( $v v$. 13-15; refer Tables 1 and 2). Within this obscure onomasticon of $v v$. 10b-12a, Beth-le-aphrah stands out as a problem due to the grammatically difficult position of the -3 attached to the nomen rectum of the toponymic construct: The לִ לַפְּרָה

\footnotetext{
*) This work is dedicated to the memory of Hanan Eshel (ז). I would like to acknowledge Anson Rainey, Paul Wright, and Professor Eshel for their involvement with the research presented here, which was originally submitted as a thesis to Jerusalem University College. I also want to thank George Pierce for his contributions. Any errors or shortcomings, however, are my own.
} 
Table 1. Towns of Micah 1:10-12a

Ancient Name

Gath

Beth-le-aphrah

Shaphir

Zaanan

Beth-ezel

Maroth
Modern Toponym

Map Reference

135.123

129.113

Table 2. Towns of Micah 1:13-15

Tell eș-Ṣâfi

Tell el-'Areini

Unknown

Unknown

Unknown

Unknown

\section{Modern Toponym}

Tell ed-Duweir

Tell ej-Judeidah

Tell Beiḍā

Tell Șandahannah

Tell esh-Sheik Madkûr
Map Reference

135.108

141.115

145.116

140.111

150.117

ambiguous context of Mic 1:10b-12a has obfuscated any precise location and identification of Beth-le-aphrah (as well as the other towns of the stanza), and as a result this problematic place name is at times omitted in modern reconstructions of the notoriously difficult text of Mic 1:10-16. ${ }^{1}$ The various readings and reconstructions of Mic 1:8-16, however, are not entirely satisfactory and only confirm the enigmatic nature of the topographical context and toponymic contents in $v v$. 10-12a.

The contrast between $v v$. 13-15 and 10-12a has led to different theories, including several that involve separate topographical interpretations of each stanza. Although many studies place $v v$. 10-12a in the Shephelah (the loca-

1) See for instance S. J. Schwantes, “Critical Notes on Micah 1:10-16”, VT 14 (1964), p. 456; and J. L. Mays, Micah: A Commentary (OTL; Philadelphia, 1976), p. 49. The reconstruction... עפרה בכרמי בית (see BHS), was offered in K. Elliger, "Die Heimat des Propheten Micha", ZDPV 57 (1934), p. 90, and was based solely on his conjectural theory regarding damage to the original scroll. This theory is no longer followed in light of the manuscript evidence from Wâdī Murabba'at (Mur 88); refer to A. S. van der Woude, "Micah I 10-16", in Hommages à André Dupont-Sommer, ed. A. Caquot and M. Philonenco (Paris, 1971), pp. 347-349 and R. C. Lux, "An Exegetical Study of Micah 1:8-16" (Doctoral Dissertation, University of Notre Dame, 1976), pp. 35-37. 
tion of $v v \cdot 13-15),{ }^{2}$ some have proposed instead an area north of Jerusalem, ${ }^{3}$ while others have suggested Philistia. ${ }^{4}$ These theories, however, do not address the toponymic problem of Beth-le-aphrah, nor do they offer any new insight into its location. The toponymic and topographical difficulties have recently led Amitai Baruchi-Unna to reconstruct Mic 1:10b to read two toponyms (Bethel and Ophrah), which removes the problematic place name Bethle-aphrah and provides a geographical context in the highland plateau areas north of Jerusalem. ${ }^{5}$ Yet, this and other attempts to amend or remove the toponym Beth-le-aphrah are unsupported by any ancient manuscript. ${ }^{6}$ In fact, they are contradicted by the early versions where the obscure place name

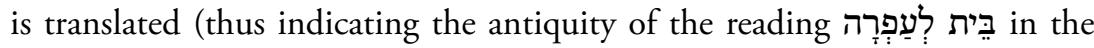
MT). ${ }^{7}$ Furthermore, none of these hypothetical readings offers any coherent

2) See, for instance, Y. Aharoni, The Land of the Bible: A Historical Geography, ed. A. F. Rainey, trans. A. F. Rainey, Revised and enlarged edition ed. (Philadelphia, 1979; reprint Wipf and Stock Publishers 1998), p. 392; and A. F. Rainey and R. S. Notley, The Sacred Bridge: Carta's Atlas of the Biblical World (Jerusalem, 2006), p. 243.

3) A. S. van der Woude ("Micah I 10-16", pp. 350-352) divided the passage according to meter and interprets $v v$. 10-12 as a lament for towns in the northern vicinity of Jerusalem, and $v v$. 13-15 as a judgment oracle against Lachish and its environs.

4) G. A. Smith, The Book of the Twelve Prophets, Commonly Called the Minor, New and rev. ed. (Garden City, NY, 1929), pp. 409-411; Smith's suggestion was based on the reference to Gath

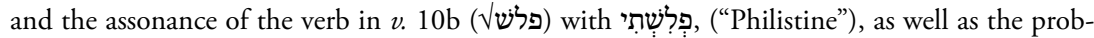
lematic identification of Shaphir in $v$. 11a with es-Sawaffir (near Ashdod), based on an equally difficult reference in the Onomasticon of Eusebius. More recently, scholars have proposed a Philistine setting based on the decline of Gath, as well as $2 \mathrm{Kgs} \mathrm{18:8;} \mathrm{suggested} \mathrm{in} \mathrm{W.} \mathrm{Rudolph,}$ Micha, Nahum, Habakuk, Zephanja (KAT; Gütersloh, 1975), p. 45. Detailed arguments can be found in S. Mittmann, "Hiskia und die Philister", JNSL 16 (1990), pp. 100-102 and "Eine prophetische Totenklage des Jahres 701 v. Chr (Micha 1:3-5a. 8-13a. 14-16)”, JNSL 25 (1999), pp. 39-43.

5) A. Baruchi-Unna, "Do Not Weep in Bethel: An Emendation Suggested for Micah i 10", VT

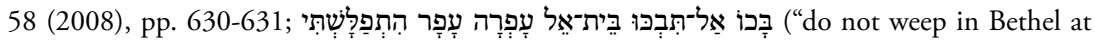
all. Ophrah roll yourself in the dust").

6) Wolfram von Soden ("Zu einigen Ortsbenennungen bei Amos und Micha", ZAH 3 [1990], p. 217) had conjectured that Beth-le-aphrah was a poetically distorted form of the place name

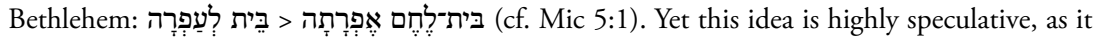
is dependent upon an assumption that every place name in Mic 1:10b-12a was poetically distorted, and it requires a town (Bethlehem) outside of the general location of the rest of the passage (Jerusalem, not withstanding).

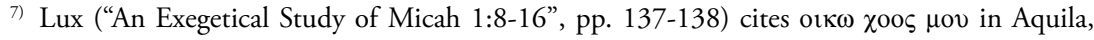

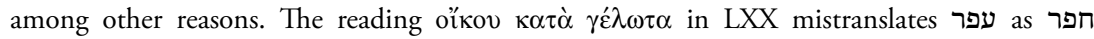
("shame"). As Delbert Hillers noted (Micah: A Commentary on the Book of the Prophet Micah, [Hermeneia; Philadelphia, 1984], p. 25 n. c), some versions simply omit the ל. These omissions, 
picture of the stanza's topographical relationship with the following stanza ( $v v$. 13-15). ${ }^{8}$ The mention of Gath and Zaanan provide limited data that indicates, nonetheless, that the setting of Mic 1:10-12a was relatively close to that of $v v$. 13-15. A comparison of this data with the geographical principles observed in Mic 1:13-15 will provide a better understanding of the topography of $v v \cdot 10-12 \mathrm{a}$ and serve as the basis for a new proposal for the location of Beth-le-aphrah.

\section{Micah's Topographical Lament}

The literary form of Mic 1:8-16 is that of the lament and the poem itself is composed of four stanzas: $v .8-9,10-12,13-15$, and $v .16 .^{9}$ Two stanzas bracket the poem with imagery descriptive of mourning; the first begins with lamentations as well as exposure and self-mutilation $(v v .8-9)$ while the fourth ends with tonsure (the one-line strophe of $v .16) .{ }^{10}$ The two stanzas between these brackets continue the motif of the lament but are defined by individual

at the least, recognize the form בית/-עפר (for example domo Pulveris in the Vulgate), which stands against the possibility of other place names such as Bethel and Bethlehem to explain the $\zeta$ of the MT.

8) For instance, Baruchi-Unna ("Do Not Weep in Bethel", pp. 630-631) fails to explain the distance between Gath of the Philistines, located in the Coastal Plain, and the towns of Bethel and Ophrah in the Central Highlands north of Jerusalem.

9) While most would agree with a division between $v v$. 8-9 and the following verses, previous studies have failed to recognize that $v .16$ is a one-line strophe that continues the lament. Furthermore, most studies note the role of the two clauses of $v v .9$ and 12; H. W. Wolff, Micah: A Commentary, trans. G. Stansell (Minneapolis, 1990), pp. 48-49; and N. Na'aman, "'The House-of-No-Shade Shall Take Away Its Tax from You' (Micah i 11)”, VT 45 (1995), p. 517. Yet the motifs of lament and geography are interwoven by the images associated with Jerusalem in $v .9 \mathrm{~b} \beta$ and $v .12 \mathrm{~b} \beta$, which effectively bracket the second strophe (and the toponyms of $v v$. 10-12a). Moreover, this structure brings a certain focus on Lachish, which begins the third strophe and occupies and entire verse, although Wolff (Micah, p. 50) saw vv. 13b-14a $\alpha$ as later insertions. The anaphoric sense of עַל-זאת, beginning $v$. 8, relates $v v$. 5-7 and the fate of the northern kingdom to the doom described for the southern kingdom in $v v$. 8-16.

10) For discussions of the lament form in this passage, in addition to the major commentaries, see G. Stansell, Micah and Isaiah: A Form and Tradition Historical Comparison, ed. J. J. M. Roberts (SBL Dissertation Series; Atlanta, Ga., 1988), pp. 40-47; F. W. Dobbs-Allsopp, Weep, O Daughter of Zion: A Study of the City-Lament Genre in the Hebrew Bible (Biblica et Orientalia 44; Roma, 1993), pp. 134-137; and Y. Hoffman, “The Wandering Lament: Micah 1:10-16”, in M. Cogan and D. E. Kahn (ed.), Treasures on Camels' Humps: Historical and Literary Studies from the Ancient near East Presented to Israel Eph'al (Jerusalem, 2008), pp. 89-92. Hoffman pays particular attention to the paronomasia of the toponyms as part of the lament. 
wordplay on eleven place names ( $v v \cdot 10-12 \mathrm{a}$ and 13-15), utilizing paronomastic renditions of several toponyms as well as poetic interplay with their root or etymology. ${ }^{11}$ The poem, therefore, consists of two inextricable motifs that are combined with terminology indicative of inheritance (and disinheritance) as well as exile, collectively presenting an image of national catastrophe. The catastrophe is played out in a topographical setting that runs through the second and third stanzas ( $v v .10-12 \mathrm{a}$ and 13-15), yet the second stanza consists of unknown and unidentified place names (such as Bethle-aphrah, along with Shaphir, Beth-ezel, and Maroth). ${ }^{12}$ The topographical setting of $v v$. 10-12a, however, can be reconstructed based on the geographical sense observed in the better-known place names found in $v v$. 13-15.

The common feature of both the second and third stanzas is the wordplay rendered on each proper noun. ${ }^{13}$ This unifying factor shows that it is possible to use $v v \cdot 13-15$ as a template for the interpretation of $v v \cdot 10-12 \mathrm{a}$. For instance, the orthography of the relatively familiar toponyms in Mic 1:13-15 suggests that the lesser-known toponyms of $v v$. 10a-12b are not poetic distortions. ${ }^{14}$ Furthermore, the known locations of Lachish, Mareshah, and Adullam, (along with probable locations of Moresheth-gath and Achzib), ${ }^{15}$ show

11) W. G. E. Watson, Classical Hebrew Poetry: A Guide to Its Techniques (JSOTSup; Sheffield, 1984), pp. 244. Several commentaries offer detailed treatments on each toponym and its poetic interplay, see for instance Wolff, Micah: A Commentary, pp. 59-64; and F. I. Andersen and D. N. Freedman, Micah: A New Translation with Introduction and Commentary, 1st ed. (Anchor Bible; New York, 2000), pp. 207-212. These commentaries, however, are often deficient in their geographical discussions (particularly regarding the location of Gath).

12) See similarly, Mays, Micah, pp. 52-53, although he identifies Beth-le-aphrah with Khirbet et-Tayyibeh in the Central Highlands (see below) and follows Elliger's unnecessary reconstruction of Giloh in Mic 1:10a.

13) Additionally, Andersen and Freedman, Micah, p. 204, identify the term יוֹשֶֶׁת ("dweller”) in $v v$. 11, p. 12, pp. 13 and 15 as a unifying factor.

14) Contra von Soden, "Zu einigen Ortsbenennungen bei Amos und Micha”, pp. 216-219; followed by Naaman, "Micah i 11", pp. 519-521. None of the better-known place names in $v v$. 13-15 display anything more than the expected orthographical variation, although von Soden's study (ibid., p. 17) suggested that these verses consisted of wordplay in contrast to the poetic distortions of the earlier stanza. The orthographical variation, however, is seen in both stanzas and was certainly influenced by poetic license. For example, Mareshah is spelled defectively (מָרָשָה), "the inheritor" (m. sg nominal participle of ירששר). The opposite is seen in Zaanan of $v$. $11 \mathrm{~b} \alpha$,

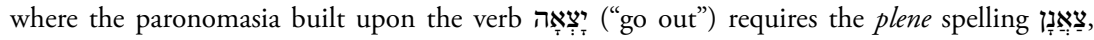
which reveals the toponymic root צאן ("flock [of livestock]") as opposed to the defective spelling צִנָ (Josh 15:37).

15) Refer to Table 2. 
that the places mentioned in $v v$.13-15 shared a similar location: the lowland hills, known as the Shephelah. ${ }^{16}$ With the exception of Moresheth-gath, the prophet's hometown, all of the settlements of third stanza ( $v v$. 13-15) are found in the Shephelah districts of Josh 15:33-44. Only Zaanan of the second stanza $(v .11 \mathrm{~b})$ is found in this same administrative document (listed as Zenan in Josh 15:37). ${ }^{17}$ Yet the placement of Zenan/Zaanan in the same district as Lachish (Josh 15:37-41), along with Gath's proximity to the Shephelah, indicates that the general area of $v v$. 10-12a was near that of $v v$. 13-15. Finally, it should be noted that $v v$. 13-15 reveals a schematic (albeit indirect) movement northwards, beginning at Lachish and ending at Adullam.

The orientation of $v v$. 13-15 compares with that of $v v$. 10-12a (again based on the limited data available) beginning with Gath in the north. The identification of Gath with Tell eș-Ṣâfi ( $v$. 10a) and the general locality of Zaanan (v. 11b $\alpha$ ) somewhere in the Nahal Lachish indicate a movement southward in the second stanza (toward Lachish). ${ }^{18}$ Thus, the geographical motif of Mic 1:10-15 reflects a shift in orientation between the second and third stanza that begins with Gath and moves south towards Lachish before moving north towards Adullam (and presumably Jerusalem). The topography of the southward march in $v v$. 10-12a, from northeastern Philistia into the southwestern Shephelah, corresponds with the Inner Coastal Plain. ${ }^{19}$ This area was a border frontier between western Judah and Philistia that ran parallel to the Shephelah (and hence, $v v$. 13-15), and thus represents the most viable area for the location of Micah's "lost towns" that were mentioned alongside Gath of the Philistines ( $v v, 10-12 \mathrm{a})$.

16) Hillers (Micah, p. 24) made a similar observation in his initial remarks on the passage.

17) D. Kellermann, "Überlieferungsprobleme alttestamentlicher Ortsnamen", VT 28 (1978), pp. 425-427. For von Soden (" $\mathrm{Zu}$ einigen Ortsbenennungen bei Amos und Micha”, p. 218), the variation represented another example of a poetically distorted toponym.

18) A. F. Rainey, "The Identification of Philistine Gath-a Problem in Source Analysis for Historical Geography”, in Eretz-Israel 12: Nelson Glueck Volume (Jerusalem, 1975), pp. *63-*76; and W. M. Schniedewind, “The Geopolitical History of Philistine Gath”, BASOR 309 (1998), pp. 69-77. The Bar-Ilan University excavations led by Aren Maeir at Tell eș-Ṣâfi /Tel Zafit have revealed a large Philistine city, which strongly indicates that the archaeological site was Gath of the Philistines. See conveniently A. M. Maeir, "Zafit, Tel”, in E. Stern (ed.), The New Encyclopedia of Archaeological Excavations in the Holy Land V: Supplementary Volume, ed. E. Stern (Jerusalem, 2007), pp. 2080-2081.

19) E. Orni and E. Efrat, Geography of Israel, pp. 3rd rev. ed. (Jerusalem, 1971), p. 35 and Y. Karmon, Israel: A Regional Geography (London and New York, 1971), pp. 222-223. 


\section{Beth-le-aphrah as a Toponymic Problem}

The obscure and difficult nature of Beth-le-aphrah begins with its grammatical form, therefore it is important to start with the problematic $ל$ that is affixed within a compound toponym made up of two otherwise common elements (עפר and (עית). ${ }^{20}$ Most analyses of Beth-le-aphrah state that its form is unattested elsewhere, ${ }^{21}$ yet Josephus (War 4, 445) mentions a village in the toparchy of Judea with a similar construction, Bethletepha $(\mathrm{B} \varepsilon \theta \lambda \varepsilon \pi \tau \eta v \varphi \hat{\omega} v){ }^{22}$ Certainly this is a later source, but Bethletepha is a construct that utilizes the toponymic element בית and it occurs in the same general area, the lowland hills (Shephelah), as do the place names in Mic 1:10-15. In addition, the occurrence of $ל$ as a bound morpheme on a toponym can be observed as well in Lidebir (לִדְבר in Josh 13:26), which is commonly written Lo-debar (לוֹדְבָר in 2 Sam 9:4). ${ }^{23}$ A study of the textual witnesses to Mic 1:10b, by T. J. Lux, concludes that it is preferable to presuppose a 2 as part of the original

20) The common noun בית a toponymic element could reference a temple dedicated to the village deity, see Aharoni, The Land of the Bible, p. 108. It seems more likely, in this case, that the term is used to refer to a resident kinship-group; for a discussion of clans and villages in Iron Age Israel, see J. D. Schloen, The House of the Father as Fact and Symbol: Patrimonialism in Ugarit and the Ancient near East (Studies in the Archaeology and History of the Levant; Winona Lake, IN, 2001), pp. 159-163. Toponyms with עפר are typically rendered as Ophrah, see e.g., Josh 18:23. The physical nature of עפר ("dust”) probably relates to the soil quality of the area, Aharoni, The Land of the Bible, p. 109.

21) See, for example, Andersen and Freedman, Micah, p. 218.

22) Pliny the Elder (Natural History 5, xv: 70) records the place name as Betholeptephenen. The toponym is usually explained as *Beth-netofa and located at Beit-Nattif (M.R. 149.122) in the Shephelah; see M. Avi-Yonah, Gazetteer of Roman Palestine (Qedem 5; Jerusalem, 1976), p. 40; and Y. Tsafrir, L. Di Segni, and J. Green, Tabula Imperii Romani: Iudaea, Palaestina (Jerusalem, 1994), p. 84. A less popular suggestion is Bêth-l'tappûh, mentioned in M. Avi-Yonah, "Bethleptepha”, in M. Berenbaum and F. Skolnik (eds.), Encyclopaedia Judaica III (Detroit, 2007), p. 535. The proper noun in Beth-letepha would be תַפ ("apple”), the name of a town in the second district of the Shephelah Josh 15:34, resulting in the conjectural *Beth-letappuah (cf. the Central Highland settlement of Josh 15:53).

23) All of these toponyms refer to the same location in the Transjordan. The place name is also spelled לאדזָרבר (2 Sam 17:27; cf. Amos 6:13); the latter reference representing a pun on the name, or possibly a local etymology (resulting in "no thing"). The variant orthography, however, may reflect some confusion regarding the otherwise rare toponymic element לאול The pejorative etymology (see Amos 6:13), compared with the variant לִדִברִ, suggests that the toponym is a compound word composed of two elements (לבר), rather than a four-radical root. The basic component, דבר VIs "pasture, field" (Isa 5:17 [possibly also Mic 2:12]; the root of the common noun מִדְבר "steppe-land”). 
orthography (in Beth-le-aphrah) rather than to postulate a later addition of the difficult particle. ${ }^{24}$ Therefore, it seems more likely that the affixed ל- ל- was originally a toponymic feature that functioned as a locative-genitive, ${ }^{25}$ or emphatic. $^{26}$

The pun on the place name Beth-le-aphrah involves the element עפר: “... roll yourself in the dust" (Mic 1:10b). ${ }^{27}$ This toponymic element is common in the Hebrew Bible, and the construct can be rendered "house in/of the dust". At some point in the Islamic period place names with this element were changed to tayyibeh ("sweet; good" in Arabic) to avoid confusion with ifrit, an Arabic word for a malevolent spirit. ${ }^{28}$ As a result, scholars have used this toponymic phenomenon to identify Beth-le-aphrah with either Khirbet et-Ṭayyibeh (M.R. 153.107) or Ṭayyibet el-'Ism (M.R. 144.107). ${ }^{29}$ Yet both

\footnotetext{
24) See Lux, "An Exegetical Study of Micah 1:8-16", p. 138. related human settlement within the local environment.
"House in place of dust"
בית /לו-עפר =
בֵַית לְעַפְרָרה >
"House in place of soil"

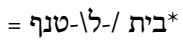

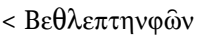
"House in pastureland"

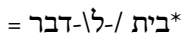
<

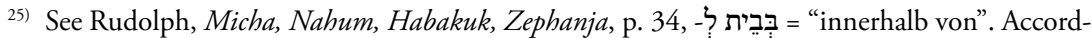
ingly, the form is interpreted as a prepositional phrase and not a toponymic element; see also E. Jenni, Die hebräischen Präpositionen (Band 3. Die Präpositionen Lamed; Stuttgart, 1992), p. 267, \$ 8465. Similarly, L. M. Luker, "Beth-le-aphrah", in $A B D$ I (1992), p. 689, refers to the as a possessive with a genitival sense. Interestingly, it is possible in all three examples to interpret the root of the nomen regens as a geographical term (i.e., עפר = "dust"). The head noun of

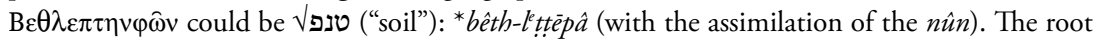
is only used as a verb in the Hebrew Bible (once, Song 5:3) and the Targums as a verb, meaning "to soil (i.e., defile)", cf. also Akk. $\tan \bar{a} p u(u), C A D 19$ Ṭ: 46-47. If these interpretations are correct, it may explain more adequately the purpose of the $/$ / in toponyms as a particle that

26) E.g., "the house of the place of dust". In this case, it would correspond to the Aramaic definite marker (rare in Hebrew, although note Lev 19:18); while its position on the head noun would match that of the Hebrew article in construct forms.

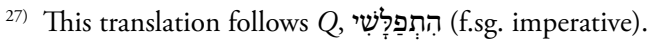

28) R. Hartmann, "Zum Ortsnamen at-Ṭjjiba”, ZDMG 65 (1911), p. 538; Rudolph, Micha, Nahum, Habakuk, Zephanja, p. 45; Aharoni, The Land of the Bible, p. 121; Rainey and Notley, The Sacred Bridge, p. 243. See the discussion in Y. Elitsur, Ancient Place Names in the Holy Land: Preservation and History (Jerusalem \& Winona Lake, Ind., 2004), pp. 272-279.

29) Khirbet et-Tayyibeh (M.R. 153.107) was initially identified as Beth-le-aphrah by A. Saarisalo, "Topographical Researches in the Shephelah", JPOS 11 (1931), pp. 102-103 and is cautiously followed by Aharoni, The Land of the Bible, p. 432; cf. Y. Aharoni et al., The Carta Bible Atlas, Corrected 4th ed. (New York, 2002), p. 118, map 153. Zecharia Kallai (Historical Geography of the Bible: the Tribal Territories of Israel [Jerusalem \& Leiden, 1986], p. 383 n. 108) tentatively suggested Tayyibet el-'Ism (M.R. 144.107), in the Shephelah east of Mareshah and 
sites are located outside of the area suggested for $v v \cdot 10-12 \mathrm{~b}$, as Tayyibeh is in the Central Highlands of Judah and Tayyibet el-'Ism is found in the Shephelah, although east of Mareshah and Lachish. In fact, this toponymic phenomenon may represent a false lead in the search for Beth-le-aphrah, as it is

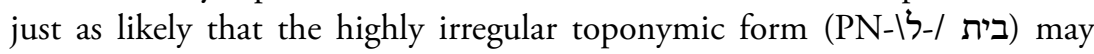
indicate that the PN (עַפְרָה ) was a regional designation, such as a valley, rather than a place name associated with a single site. ${ }^{30}$

\section{Tell el-'Areini = Beth-le-aphrah?}

The famous nineteenth century explorer and biblical scholar George Adam Smith noted in his commentary on Micah that the element עפר (in Beth-leaphrah) might be preserved in the Arabic place name Wâdī el-Ghufr. ${ }^{31}$ According to Smith, the valley was located south of Beit-Jibrin (in close proximity to Mareshah), and the Survey of Western Palestine placed it in the Nahal Lachish. ${ }^{32}$ The valley system in question flows west and north, and eventually

Lachish. Among the problems of this identification is that el-'Ism's archaeological profile appears to be later than the Iron Age.

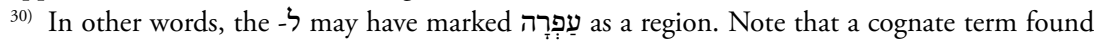
in an Old South Arabian inscription (C 570), 'FR, may have designated a type of field or cultivable valley; see the alternate suggestion in A. F. L. Beeston, Sabaic Dictionary: English, French, Arabic (Publication of the University of Sanaa, Yar; Louvain-la-Neuve \& Beyrouth, 1982), p. 14. It is also possible that the proper noun refers to a kinship group, for instance the Kenite clan name עָפְָרָה in the genealogy of $1 \mathrm{Chr}$ 4:14 may represent the same locality as Beth-leaphrah, as noted by Hillers, Micah, p. 25 (citing Edward Robinson).

31) Smith, The Book of the Twelve Prophets, p. 410 n. 3. Although Smith expressed doubts in equating the valley with Beth-le-aphrah, based on location, he used the Arabic toponym ghufr ("young ibex") to suggest that עָפָר (me weaning the same in Hebrew). See similarly Elitsur, Ancient Place Names, pp. 279-280. Elsewhere, the Arabic toponym ghufr is understood as "guard" (or "escort"); see E. H. Palmer, The Survey of Western Palestine, vol. 4. Arabic and English name lists collected during the survey (London, 1881), p. 381; and J. J. Simons, The Geographical and Topographical Texts of the Old Testament, vol. 2 (Studia Francisci Scholten memoriae dicata; Leiden, 1959), \$ 1530. Elitzur (ibid., p. 278) notes a few examples in which עפר was not changed to Tayyibeh. Wâdī el-Ghufr, where $\dot{g}=\boldsymbol{y}$ (as in the place name Gaza), can be listed as another example.

32) In fact, the entire course of the Nahal Lachish holds several different Arabic names. British Mandate 1:20,000 maps show that as the valley bends north and west at Lachish, the name changed from el-Ghufr to Wâdī el-Qubeiba (after the former Arab village adjacent Tell ed-Duweir [Sheet 13-10]) and then continues west to the coastal plain and quickly changes to Wâdi et-Tell (Sheet 13-11), no doubt due to the prominent mound (el-Areini) that guards its west- 


\section{debouches in the Inner Coastal Plain at Tell esh Sheikh Ahmed el-'Areini (Tel} 'Erani in Hebrew). ${ }^{33}$ This archaeological site, Tell el-Areini, should be identified as Beth-le-aphrah of Mic 1:10b based on a combination of factors that include its location in relation to both Gath and Lachish, as well as its position along the Nahal Lachish (which preserves the ancient toponym עפר), and finally its archaeological profile.

The ancient identity of el-Areini has long been a problem in regional studies of western Palestine; during the nineteenth century C. R. Conder and H. H. Kitchener suggested that the site was Libnah, ${ }^{35}$ while in the early twentieth century William F. Albright identified it as Gath of the Philistines. ${ }^{36}$ Both attempts to identify el-Areini were influenced by the prominent shape of the mound, ${ }^{37}$ which was the result of a site formation-process specific to the Early Bronze Age. ${ }^{38}$ Yet the archaeological excavation of the mound shows

ern entrance. It is important to note, however, that the valley is a single geographical feature (regardless of its multiple names). Furthermore, the full Arabic name of the archaeological site in question, Tell esh-Sheikh Ahmed el-Areini, comes from the Muslim holy man whose wêli sits atop the mound. (Thus, the current toponym does not pre-date the Islamic period.) The suggestion that the entire length of the valley carried the name of a site situated at its terminus is supported by the fact that the valley to the south, the Wâdi el-Hesi corresponds with the name of the mound that guards its western entrance: the famous archaeological site of Tell el-Ḥesi.

33) Older studies sometimes refer to the site as 'Araq el-Menshiyeh, based on the former Arab village located adjacent the tell; A. F. Rainey, "Tell Sheik el-Areini”, in C. F. Pfeiffer (ed.), The Biblical World, a Dictionary of Biblical Archaeology (Grand Rapids, 1966), p. 573.

34) Smith's toponymic observation (originally published in 1896) has met with some approval; see F. M. Abel, Géographie de la Palestine, vol. 2. Géographie politique. Les villes (Paris, 1933), p. 294; J. J. Simons, Geographical and Topographical Texts of the Old Testament, \$ 1530; and Lux, "An Exegetical Study of Micah 1:8-16", pp. 139-140; yet none of these studies have offered a more precise identification.

35) C. R. Conder and H. H. Kitchener, The Survey of Western Palestine, vol. 3. Judaea (London, 1883), p. 259, and pp. 261-262.

36) W. F. Albright, "Libnah and Gath", BASOR (1921), p. 6; idem, "Contributions to the Historical Geography of Palestine", AASOR 2 (1921-1922), p. 11; and "The Fall Trip of the School in Jerusalem: From Jerusalem to Gaza and Back”, BASOR 17 (1925), p. 8. Albright's identification led to the name of the nearby Israeli moshav: Kiryat Gat.

37) For instance, Conder and Kitchener speculated that the steep slope of the tell (which is now known to be the result of Early Bronze Age fortifications) was the result of Assyrian siege works at Libnah (see $2 \mathrm{Kg}$ 19:8 = Isa 37:8). Note also Albright's comments on the "striking" appearance of el-Areini ("Contributions to the Historical Geography of Palestine”, p. 11).

38) The formative period of the el-Areini was the Early Bronze II-III, which is the phase when the site was fortified (including an earthen glacis); refer to B. Brandl, "Erani, Tel", in E. M. Meyers (ed.), The Oxford Encyclopedia of Archaeology in the Near East II (New York, 1997), p. 257. 
that Tell el-'Areini was a much smaller settlement during the first millennium than it was during earlier occupational phases. ${ }^{39}$ The first archaeological work at Tell el-'Areini, conducted by Shmuel Yeivin during the late 1950s and early $60 \mathrm{~s},{ }^{40}$ revealed that the Iron Age settlement consisted first of a small Philistine village (Iron I), followed by a fortified Judean border town (Iron II). ${ }^{41}$ The material remains of the latter phase included epigraphic material from the time of Hezekiah (20 lmlk-seal impressions) and a destruction level attributed to Sennacherib's campaign of $701 \mathrm{BCE} .{ }^{42}$ Although the identification proposed here is tentative, the archaeological profile of the mound-a small Judean border fortress destroyed by Sennacherib-matches that of the settlements lamented in Mic 1:10b-12a. ${ }^{43}$

\section{Historical Synthesis}

The topographical interpretation of Mic 1:10-12b, and the identification of Beth-le-aphrah with Tell el-Areini, coincides nicely with the emerging picture of Judah's western boundary prior to the Assyrian invasion of 701 BCE. The topographical setting of $v v$. 10-12b roughly corresponds to "southwestern Judah", so-called by Jeff Blakely and James Hardin who traced the kingdom's western frontier along a line of fortified sites in the Inner Coastal Plain that included Tell el-Hesi, Tell Abu esh-Sheqef, and Tell el-'Areini. ${ }^{44}$ Similarly, Ron Tappy has suggested that the fourth district of the Shephelah (Josh

39) S. Yeivin, "Tell Gat”, IEJ (1958), pp. 274-276. This fact has eliminated Gath as a possible identification for el-Areini. In other words, the small Iron I-II settlements occupied only the top of a tell-site created by a larger EB II-III city. (There was a gap in occupation during the MB-LB periods.)

40) S. Yeivin, "Erani, Tel”, in E. Stern (ed.), The New Encyclopedia of Archaeological Excavations in the Holy Land II (Jerusalem, 1993), p. 418; Brandl, "Erani, Tel", p. 256. For a discussion of the Iron II stratigraphy, see J. A. Blakely and J. W. Hardin, "Southwestern Judah in the Late Eighth Century B.C.E.”, BASOR 326 (2002), pp. 32-35.

41) Brandl, "Erani, Tel”, p. 257.

42) Brandl, "Erani, Tel”, p. 257; see the discussion of Stratum VI.

43) Anson Rainey (in Rainey and Notley, The Sacred Bridge, p. 243) has also recognized that el'Areini's profile matches the towns of Mic 1:10b-12b, and has suggested that the site may be Shaphir (v.11a), based on Eusebius's Onomasticon. The proposal is plausible, although there is nothing in the local toponymy that would favor Shaphir over any of the other towns in the passage.

44) Blakely and Hardin, "Southwestern Judah in the Late Eighth Century B.C.E.", pp. 11-64. Included also were the western lowland sites of Tell Zeitah and Tell Bornât. 
15:42-44) extended further west than the other Shephelah districts, and included the area west of the Nahal Guvrin as it feeds into the Coastal Plain. ${ }^{45}$ This district, which includes Mareshah and Achzib (Josh 15:44; cf. Mic 1:14a-15b), would have spanned the area of Tell Zeitah (which Tappy suggests may be Libnah of Josh 15:42). Furthermore, excavations at the Inner Coastal Plain site of Tell eṣ-Ṣâfi (north of Tell Zeitah) have shown that during the eighth century, Judah controlled the once great Philistine city of Gath. ${ }^{46}$ The archaeological picture of western Judah coincides to some degree with Siegfried Mittmann's theory of Judean expansion into Philistia during the reign of Hezekiah. ${ }^{47}$ The picture, however, is one of a westward extension of Judean settlements (rather than annexed territory) that was ultimately lost during Sennacherib's third campaign. The western frontier regions, which were expropriated in the early seventh-century by the Assyrians to their loyal Philistine vassals, ${ }^{48}$ are precisely the same areas that were lamented in Micah's first chapter ( $v v$. 10-15): the Inner Coastal Plain and the western Shephelah (see map below). ${ }^{49}$

Several different historical periods have been suggested for Micah's oracle, ${ }^{50}$ however the comprehensive destruction wrought by Sennacherib in his third

45) R. E. Tappy, "Historical and Geographical Notes on the "Lowland Districts" of Judah in Joshua XV 33-47”, VT 58 (2008), pp. 383-388.

46) A. Zukerman and I. Shai, “'The Royal City of the Philistines' in the 'Azekah Inscription' and the History of Gath in the Eighth Century BCE”, UF 38 (2006 [2007]), pp. 738-741; for the ninth century decline of Gath, see A. M. Maeir, "The Historical Background and Dating of Amos vi 2: An Archaeological Perspective from Tell es-Safi/Gath”, VT 53 (2004), pp. 319-334.

47) Mittmann, "Eine prophetische Totenklage des Jahres 701 v. C”, pp. 53-57; idem., "Hiskia und die Philister".

48) COS 2.199B, p. 303. For the late-eighth century destruction of the Shephelah of Judah, see I. Finkelstein, "The Archaeology of the Days of Manasseh”, in M. D. Coogan, C. J. Exum, and L. E. Stager (eds.), Scripture and Other Artifacts: Essays on the Bible and Archaeology in Honor of Philip J. King (Louisville, 1994), pp. 169-187. See also A. Faust, "Settlement and Demography in Seventh-Century Judah and the Extent and Intensity of Sennacherib's Campaign", PEQ 140 (2008), pp. 182-183. Even though Faust challenges the common historical reconstructions of seventh century Judah, he concedes that the kingdom's borders receded past the Shephelah.

49) Hillers (Micah, p. 30) came to a similar conclusion, although he did not specify the geographical area. The conclusion is more appropriate for the place names in $v v$. 10-12a, as those of $v v$. 13-15 seem to have been reoccupied by Judah in the late Iron II; note, for example, Lachish Level II.

50) For a brief review of the various historical settings, such as the Syro-Ephraimite War, and the different possible Assyrian incursions (i.e., 720, 712, or $701 \mathrm{BCE}$ ), refer to G. Fohrer, "Micha 1", in F. Maass (ed.), Das ferne und nahe Wort. Festschrift Leonhard Rost (BZAW 105; Berlin, 1967), pp. 67-68 (who dates the passage to 712); Na'aman, "Micah i 11", pp. 525-527 


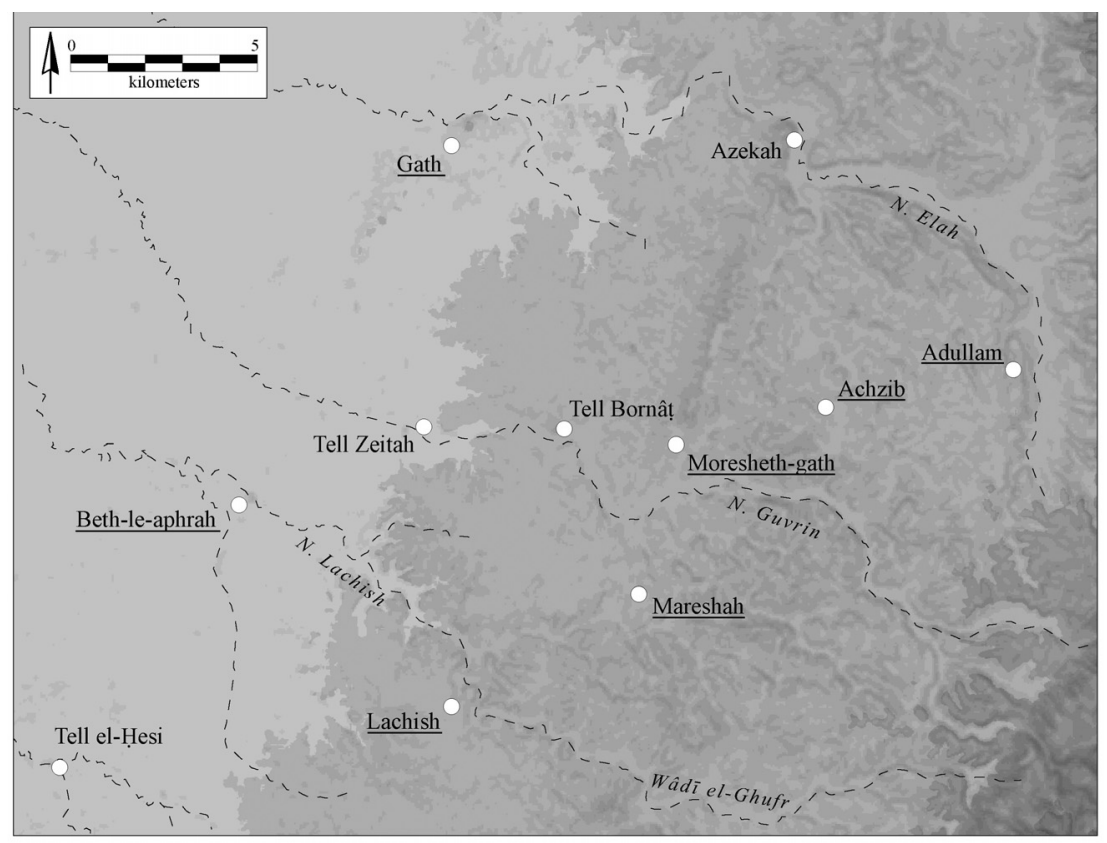

Map. Proposed locations for Micah 1:10-15. Map by George A. Pierce, University of California, Los Angeles.

campaign represents the most appropriate background for interpreting Mic 1:10-15. ${ }^{51}$ The reference to Gath and Lachish in Assyrian and biblical texts coheres with the prominent position of both cities in leading off the second and third stanzas of Micah's oracle of doom ( $v v$. 10a and 13, respectively). ${ }^{52}$ Tell el-Areini's position between Gath (Tell eș-Ṣâfi) and Lachish

(preferring a 701 date). See also Hoffman, “The Wandering Lament: Micah 1:10-16”, pp. 92-94 (who sees its origins in the Philistine aggression of the Syro-Ephraimite War, 738-734, but argues that it was taken up again during the conflict of 701).

51) Most studies date Mic 1:8-16 to Sennacherib's third campaign, see Aharoni, The Land of the Bible, p. 392; N. Na'aman, "Sennacherib's Campaign to Judah and the Date of the lmlk Stamps", VT 29 (1979), pp. 83-86; Rainey and Notley, The Sacred Bridge, p. 243.

52) The role of Lachish in the Assyrian invasion is well known, as it is depicted and documented in Sennacherib's palace reliefs (the Layard reliefs), mentioned in biblical sources (2 Kgs 18:14-17; Isa 36:2; in addition to Mic 1:13), and evident in the destruction layer of Lachish Level III (which has become a type-site for the analysis of Judah during the late-eighth century); see D. Ussishkin (ed.), The Renewed Archaeological Excavations at Lachish (1973-1994) I-V (Tel Aviv, 2004). The role of Gath, based on the "Azekah Inscription" is more problematic. 
(Tell ed-Duweir) fits the reference to Beth-le-aphrah in Mic 1:10b. The place names in Mic 1:10-15 were most likely among the " 46 walled cities" of Hezekiah that Sennacherib claims to have destroyed, ${ }^{53}$ and Beth-le-aphrah along with the obscure settlements of $v v$. 10-12a may represent territory that was never recovered by the Kingdom of Judah. ${ }^{54}$ As Delbert Hillers observed in his commentary, ${ }^{55}$ the historical context of the Assyrian crisis that was collectively suffered by the settlements of Mic 1:10-15 is reflected in the final words of the oracle $(v .16)$ : "for they have been exiled from you". Outside of Mic 1:10-12a, Beth-le-aphrah and the settlements of Judah's western frontier were forgotten; following the tumultuous period of the late-eighth through seventh centuries BCE they became little more than places in the dust.

The Assyrian text that describes a siege of Azekah (COS 2.119D), along with a Philistine royalcity, is dated by some to Sargon II (and a putative campaign of 715 BCE; ref. to Isa 20:1); see M. Cogan and H. Tadmor, II Kings. A New Translation with Introduction and Commentary, ed. D. N. Freedman (AB 11; New York, 1988), pp. 261-262 n. 6. Furthermore, some reconstruct Ekron as the name of the "royal city of the Philistine" (lost in a lacuna in the inscription), instead of Gath. See, for example Mittmann ("Hiskia und die Philister", pp. 98-99) and among others Nadav Na'aman, who first proposed the tablet join ("Sennacherib's 'Letter to God' on His Campaign to Judah", BASOR 214 [1974], pp. 25-39), and now supports the reading "Ekron". (See Na'aman "Ekron under the Assyrian and Egyptian Empires", BASOR 332 [2004], p. 85.) Yet, based on the history of Assyrian expansion into this region, as well as the archaeology of Gath and Ekron, Gath ( ${ }^{\mathrm{IRI}}$ Gimtu) remains the best candidate in this particular text; refer to K. L. Younger Jr., "Assyrian Involvement in the Southern Levant at the End of the Eighth Century B.C.E.", in A. G. Vaughn and A. E. Killebrew (eds.), Jerusalem in Bible and Archaeology: the First Temple Period (Atlanta, 2003), pp. 238-239; and Zukerman and Shai, “...the History of Gath in the Eighth Century BCE”, pp. 754-759.

53) Na'aman, "Sennacherib's Campaign to Judah and the Date of the lmlk Stamps", pp. 83-85.

54) The lack of correspondence between Mic 1:11-12a and Josh 15 (Zaanan notwithstanding) indicated to Na'aman that they reflect different historical periods, with the administrative list in Joshua dating to the time of Josiah (late seventh-century) after Micah's lamented towns had been lost; "Micah i 11", pp. 524-525; idem., "Hezekiah and the Kings of Assyria", Tel Aviv 21 (1994), pp. 235-254.

55) Hillers, Micah, p. 30. 